\title{
Implikasi Penerapan Sistem Manajemen Mutu ISO 9001:2015 di Madrasah (Studi Kasus di Madrasah Aliyah Nahdlatul Ulama Banat, Kudus, Indonesia)
}

\author{
Siti Isnaini*, Fatah Syukur, Agus Khunaifi
}

Universitas Islam Negeri Walisongo, Semarang, Indonesia

\begin{abstract}
ABSTRAK
Kompetisi dunia kerja di era global ini tidak hanya terjadi di level nasional melainkan internasional. Realitas ini menuntut lembaga-lembaga pendidikan memiliki kualitas lulusan berstandar internasional. Penelitian ini bertujuan mengkaji implikasi penerapan Sistem Manajemen Mutu ISO 9001:2015 di Madrasah Aliyah NU Banat Kudus. Penelitian ini menggunakan pendekatan kualitatif, dengan teknik observasi, wawancara, dan dokumentasi. Analisis data melalui tiga tahap, yaitu reduksi data, penyajian data, dan penarikan kesimpulan. Berdasarkan dari teori Deming, hasil penelitian ini menunjukkan bahwa pada tahap perencanaan (plan); madrasah merumuskan sasaran mutu, isu-isu internal eksternal, resiko-peluang, serta kebutuhan dan harapan pihak berkepentingan. Tahap pelaksanaan (do); madrasah melakukan komunikasi, sosialisasi dan menggalang dukungan untuk menjamin proses Sistem Manajemen Mutu ISO 9001:2015 di madrasah. Tahap pemeriksaan (check); madrasah melakukan audit internal, audit eksternal dan menyebarkan angket layanan. Tahap peningkatan berkelanjutan (act); madrasah menggunakan hasil angket layanan yang telah disebar dan juga meningkatkan grade dalam sasaran mutu. Implikasi penerapan sistem ini diantaranya terciptanya sinergitas kebutuhan akreditasi madrasah, peningkatan citra madrasah, peningkatan kualitas program, dan peningkatan kedisiplinan.
\end{abstract}

Kata Kunci: penerapan; sistem manajemen kualitas ISO 9001:2015; madrasah

\begin{abstract}
Competition in the world of work in this global era does not only occur at the national level but at the international level. This reality demands that educational institutions have graduate quality with international standards. This study aims to examine the implications applicating of the ISO 9001: 2015 Quality Management System at Madrasah Aliyah NU Banat Kudus. The method used is a qualitative approach, using observation techniques, interviews, and documentation. While the data analysis through three stages, namely data reduction, data presentation, and drawing conclusions. Based on Deming' $s$ theory, the results of the study found that at the planning stage (plan); madrasah formulates quality objectives, internal and external issues, risks, and needs and expectations of interested parties. Implementation stage (do); madrasahs communicate, socialize and mobilize support to ensure the ISO 9001: 2015 Quality Management System process in madrasah. The inspection stage (check); madrasah conducts internal audits, external audits and distributes service questionnaires. Continuous improvement stage (act); madrasah uses the results of the service questionnaire that has been distributed and also increases the grade in the quality objectives. The implications of implementing this system include the creation of synergies in the need for madrasah accreditation, improving the image of madrasah, improving program quality, and improving discipline.
\end{abstract}

Keywords: aplication; ISO 9001: 2015 quality management system process; madrasah

\section{PENDAHULUAN}

Saat ini tuntutan terhadap kualitas di dunia pendidikan merupakan tuntutan yang sangat logis. Hal ini dikarenakan luaran dunia pendidikan saat ini akan berkompetisi secara global. Kompetisi tidak hanya di level nasional melainkan juga internasional. Kompetisi global ini menuntut lulusan dengan kompetensi profesional. Dengan kata lain lembaga pendidikan yang tidak mampu menjamin kualitas lulsannya akan

\footnotetext{
* Corresponding Author.

Email addresses: isnaini0420@gmail.com (S. Isnani), fsyukur@walisongo.ac.id (F. Syukur), agus_khunaifi@walisongo.ac.id (A. Khunaefi)
} 
tersingkir. Di samping itu tuntutan kualitas pendidikan di Indonesia sejalan dengan amanat undangundang khususnya UU No. 20 Tahun 2003 tentang Sistem Pendidikan Nasional pasal 3 yakni tentang tuntutan luaran yang berilmu, cakap, kreatif dan mandiri. ${ }^{1}$ Singkatnya tuntutan terhadap kualitas pendidikan menjadi keniscayaan.

Di sisi lain, saat ini lembaga-lembaga pendidikan di Indonesia masih banyak yang membutuhkan support guna peningkatan kualitasnya. Hal ini terlihat dari beberapa aspek diantaranya; pertama, aspek prestasi secara umum masih minim apabila dibanding lembaga-lembaga pendidikan internasional. Kedua, aspek sarana dan prasarana secara umum belum mencukupi mencakup media, gedung dan fasilitas penunjang pembelajaran lainnya. Ketiga, aspek sumber daya manusia, masih terdapat guru dan staf lembaga pendidikan, serta sistem administrasi yang tidak profesianal. ${ }^{2}$ Padahal untuk mencapai pendidikan yang berkualitas, unsur-unsur tersebut merupakan penunjang dalam peningkatan mutu pendidikan. ${ }^{3}$ Singkatnya upaya peningkatan mutu lembaga-lembaga pendidikan menjadi kebutuhan mendesak.

Salah satu upaya meningkatkan mutu lembaga pendidikan di era modern adalah dengan menerapkan standar internasional di bidang sistem manajemen mutu yang dikenal dengan ISO (International Standart Organization)9001. ISO adalah lembaga international nonpemerintah yang menjadi wadah bagi badan-badan standarisasi negara-negara anggota, para ahli, asosiasi profesi, dan asosiasi bisnis, yang berperan untuk mengembangkan sistem standar dan menetapkannya sehingga dapat diakui secara internasional. ${ }^{4}$ Pada awalnya ISO hanya digunakan dalam bidang industri saja. Namun pada saat ini dalam dunia pendidikan dirasa perlu menerapkan ISO 9001 sebagai standarisasi sistem manajemen mutu lembaga pendidikan dan mendapatkan pengakuan khalayak luas dibuktikan dengan diperolehnya sertifikat Sistem Manajemen Mutu (SMM) ISO 9001. SMM ISO 9001 sebagai penjamin mutu ini telah mengalami revisi sebanyak empat kali, yakni pada tahun 1994, 2000, 2008, dan yang terakhir pada tahun 2015. ${ }^{5}$ SMM ISO 9001:2015 inilah yang saat ini dipakai oleh beberapa lembaga pendidikan untuk menjamin mutu yang berfokus pada kepuasan pelanggan. Dalam proses pelaksanaannya SMM ISO 9001:2015 menggunakan siklus PDCA (plan-do-check-act) untuk landasan dalam melakukan perbaikan atau peningkatan berkelanjutan. Sebagai pencetus siklus PDCA, Deming mengatakan bahwa jika suatu organisasi ingin menghasilkan mutu dari produk/jasa maka roda PDCA harus berputar. ${ }^{6}$

Tidak dapat dipungkiri bahwa lembaga pendidikan yang telah tersertifikasi ISO 9001:2015 lebih dipercaya karena lembaga pendidikan tersebut telah menerapkan suatu sistem yang dapat menjamin segala proses dan pengelolaannya dilakukan sesuai dengan standar internasional. Dengan diterapkannya SMM ISO 9001:2015 lembaga pendidikan tentunya mendapatkan beberapa keuntungan, diantaranya adalah tugas dan tanggungjawab jelas sesuai dengan TUPOKSInya masing-masing. Selain itu, tidak terjadi pekerjaan yang berulang karena pekerjaan dilakukan dengan menganut sistem yang baik sehingga memperoleh kepuasan kerja.

Salah satu madrasah yang sangat memperhatikan peningkatan mutu lembaga pendidikannya ialah MA NU Banat Kudus. Dengan kearifan lokal yang dimilikinya yakni kultur pesantren dengan menjunjung tinggi ajaran islam Ahlussunnah wal Jama' ah serta senantiasa berpegang teguh pada pesan sesepuh, MA NU Banat Kudus telah menarapkan Sistem Manajemen Mutu ISO 9001:2015 untuk menjamin mutu lembaga pendidikannya. Melalui lembaga pendidikan MA NU Banat Kudus diharapkan dapat meningkatkan derajat para perempuan, sehingga MA NU Banat Kudus dapat menghasilkan output tenaga pendidik perempuan yang tidak hanya memiliki intelektual tinggi namun juga berakhlaqul karimah dengan tetap mempertahankan karakteristik nilai-nilai pemikiran islam Ahlussunnah wal Jama' ah. ${ }^{7}$

Dengan diterapkannya sistem manajemen mutu ISO 9001:2015, MA NU Banat Kudus mendapatkan beberapa kemajuan di antaranya adalah pekerjaan yang dilakukan lebih teratur dan terarah karena segala

\footnotetext{
${ }^{1}$ Undang-undang No 20, Sistem Pendidikan Nasional Pasal 3, issued 2003.

${ }^{2}$ Mochamad Iskarim, "The Quality Management of Arabic Language Education Based on The Quality Management System (SMM) ISO 9001: 2015," ALSINATUNA3, no. 2 (2018): 225-43.

${ }^{3}$ Bünyamin Celik and Ömer Hakan Ölçer, "What Is the Contribution of ISO 9001 Quality Management System to Educational Institutions?," International Journal of Academic Research in Business and Social Sciences 8, no. 6 (2018). hlm. 226

${ }^{4}$ Muhammad Noor Efansyah dan agung Nugraha, Perkembangan Dan Penerapan Sistem Manajemen Mutu ISO 9001:2015 (Banten: Wana Aksara, 2019). hlm. 4

${ }^{5}$ Sugeng Listyo Prabowo, "Implementasi Sistem Manajemen Mutu ISO 9001: 2008 Di Perguruan Tinggi (Guidelines IWA2)" (UIN-Maliki Press, 2009).

${ }^{6}$ Muhammad Fadhli, "Manajemen Peningkatan Mutu Pendidikan," Tadbir: Jurnal Studi Manajemen Pendidikan 1, no. 2 (2017): $215-40$

${ }^{7}$ Www.manubanat-kudus.sch.id, diakses 7 April 2020.
} 
pekerjaannya telah tertera pada Instruksi Kerja (IK) dan Prosedur Operasi Standar (POS). Karena sejatinya ISO 9001:2015 ini memegang prinsip "Do What You Write, Write What You Do". J Jadi segala sesuatu pekerjaan yang dilakukan harus sesuai dengan apa yang sudah direncanakan dan setelah pekerjaan itu selesai, lembaga pendidikan harus menulis, melaporkan, dan mendokumentasikannya. Sehingga segala pekerjaan lembaga pendidikan dapat ter-manage dengan baik.

Berdasarkan uraian di atas, penelitian ini di angkat untuk memberikan wawasan kepada dunia pendidikan mengenai model sistem manajemen yang dapat digunakan atau diimplementasikan guna menjamin kualitas lembaga pendidikan agar dapat bersaing dengan lembaga pendidikan lain dan menghasilkan output yang berkualitas. Sehingga fokus dalam penelitian ini ialah untuk mengetahui bagaimana implementasi Sistem Manajemen Mutu ISO 9001:2015 berdasarkan siklus PDCA (plan-docheck-act) dan implikasi dari implementasi Sistem Manajemen Mutu ISO 9001:2015 di MA NU Banat Kudus.

\section{METODE PENELITIAN}

Metode penelitian ini menggunakan pendekatan kualitatif. Pendekatan kualitatif bersifat induktif, tidak dimulai dari deduksi teori tetapi dari lapangan yakni fakta empiris. Penulis terjun ke lapangan, mempelajari suatu proses atau penemuan yang terjadi secara alami, mencatat, menganalisis, menafsirkan dan melaporkan serta menarik kesimpulan-kesimpulan dari proses tersebut ". ${ }^{9}$ Fokus dari penelian ini ialah bagaimana penerapan SMM ISO 9001:2015 berdasarkan siklus PDCA (plan-do-check-act) dan implikasi dari penerapan SMM ISO 9001:2015 di MA NU Banat Kudus. Untuk mendapatkan data penelitian, peneliti menggunakan tiga teknik pengumpulan data yaitu wawancara, observasi, dan dokumentasi. Sumber data dalam penelitian ini adalah staf manajemen mutu madrasah beserta seluruh unit kerja yang ada yaitu unit kerja kepala madrasah, unit kerja waka. kurikulum, unit kerja waka. sarana dan prasarana, unit kerja waka. kesiswaan, unit kerja kepala tata usaha, unit kerja kepala perpustakaan, dan unit kerja koordinator bimbingan dan konseling. Selanjutnya dalam menganalisis data, peneliti menggunakan teknik dimulai dari reduksi data, penyajian data, dan berakhir pada penarikan kesimpulan atau verifikasi.

\section{HASIL DAN PEMBAHASAN}

\section{Sistem Manajemen Mutu}

Sistem Manajemen Mutu dari tiga kata yaitu sistem, manajemen, dan mutu. Menurut McLeod " $A$ system is a group of elements that are integreted with the common porpose of achieving an objective"10 Sistem adalah sekelompok elemen yang terintegrasi dengan maksud yang sama untuk mencapai suatu tujuan. Selaras dengan Mc Leod, menurut Badan Standar Nasional (BSN) sistem dapat didefinisikan sebagai suatu kesatuan usaha yang terdiri dari bagian yang berkaitan satu sama lain untuk mencapai tujuan dalam suatu lingkungan yang kompleks. ${ }^{11}$ Dengan demikian sistem dapat diartikan segala interaksi secara keseluruhan yang berkaitan satu sama lain (antar subsistem-subsistem) serta bekerja sama untuk mencapai suatu tujuan dan berada pada batas lingkungan tertentu.

Manajemen berasal dari kata "to manage" yang mempunyai arti mengatur. Mengatur di sini dilakukan dengan suatu proses berdasarkan urutan dari fungsi-fungsi manajemen, jadi manajemen dapat diartikan sebagai suatu proses untuk mewujudkan tujuan yang diinginkan. ${ }^{12}$ Dalam bukunya George $\mathrm{R}$ Terry dan Leslie W. Rue, menyebutkan bahwa "manajemen adalah suatu proses atau kerangka kerja, yang melibatkan bimbingan atau pengarahan suatu kelompok orang-orang kearah tujuan-tujuan organisasional atau maksud-maksud yang nyata". Dari pengertian tersebut, manajemen dapat diartikan sebagai seni atau

\footnotetext{
${ }^{8}$ Celik and Ölçer, "What Is the Contribution of ISO 9001 Quality Management System to Educational Institutions?" 451

${ }^{9}$ Gunawan Imam, "Metode Penelitian Kualitatif Teori Dan Praktik," Jakarta: Bumi Aksara, 2013. Hal 4

${ }^{10}$ Rini Asmara, S Kom, and M Kom, "Sistem Informasi Pengolahan Data Penanggulangan Bencana Pada Kantor Badan Penanggulangan Bencana Daerah (BPBD) Kabupaten Padang Pariaman," Jurnal J-Click3, no. 2 (2017). hlm. 82

${ }^{11}$ Abdul Rahman Saleh, Erni Sumarni, and Sri Rahayu Safitri, "Kajian Analisis Kepuasan Pelanggan Pada Layanan Perpustakaan Badan Standardisasi Nasional," Jurnal Pustakawan Indonesia 13, no. 2 (2014). hlm. 33

${ }^{12}$ Saleh, Sumarni, and Safitri. hlm. 35
} 
kemampuan mengatur orang lain dalam melaksanakan segala kegiatannya untuk mencapai suatu tujuan bersama yang telah ditentukan sebelumnya.

Sedangkan mutu Menurut Kamus Besar Bahasa Indonesia (KBBI) ialah ukuran baik buruk suatu benda; kadar; taraf; atau derajat. ${ }^{13}$ Menurut Deming, mutu ialah sebuah multidimensi untuk menghasilkan sebuah produk atau layanan yang memenuhi harapan pelanggan untuk memenuhi kepuasan pelanggan. Tokoh mutu Crosby mendefinisikan mutu sebagai "conformance to requirements". Mutu adalah kesesuaian dengan persyaratan. ${ }^{14}$ Mutu juga dapat didefinisikan sebagai sesuatu yang memuaskan dan melampaui keinginan dan kebutuhan pelanggan. ${ }^{15}$ Karena sesungguhnya ketika berbicara mengenai mutu maka tidak akan bisa terlepas dari pelanggan.

Dari definisi yang yelah dijelaskan tersebut, maka dapat diketaui bahwa sistem manajemen mutu menurut International Organization far Standarization, adalah cara perusahaan untuk mengendalikan kegiatan-kegiatan yang saling berhubungan atar satu dengan yang lainnya baik secara langsung maupun tidak langsung untuk mencapai suatu tujuan yang telah ditetapkan sebelumnya. ${ }^{16}$ Karena suatu sistem bentuknya satu kesatuan utuh dan tidak dapat berdiri sendiri, maka sistem manajemen mutu dapat dikatakan sebagai sekumpulan prosedur yang terdokumentasi dan praktek-praktek manajemen yang sesuai dengan standar untuk menjamin kesesuaian suatu produk dan proses terhadap persyaratan dan kebutuhan pelanggan. ${ }^{17}$

\section{Sistem Manajemen Mutu ISO 9001:2015}

Sistem Manajemen Mutu ISO 9001:2015 merupakan hasil revisi ISO seri 9001. Pada tahun 1947 M, International Standarization Association (ISA) dengan United Nation Standarization of Coordination Commite(UNSCC) yang merupakan komite bentukan PBB menyepakati pendirian Organisasi Internasional untuk Standarisasi di Landon bersama 25 delegasi negara. Organisasi tersebut diberi nama ISO atau ISOS berasal dari bahasa Yunani yang berarti sama. Hal ini diharapkan dapat menjadi motivasi menuju kesetaraan antar negara melalui standarisasi. Organisasi ISO diresmikan pada tanggal 23 Februari tahun 1947 M dan berpusat di Genewa Swiss. ${ }^{18}$ Pada dasarnya ruang lingkup penerapan Standar Sistem Manajemen Mutu ISO 9001:2008 masih dipertahankan. Namun perbandingan persyaratan klausul antara ISO 9001:2008 dan 9001:2015 dapat ditunjukkan pada tabel 1 berikut:

Tabel 1.

\begin{tabular}{clll} 
Perbandingan persyaratan klausul ISO 9001:2008 dan ISO 9001:2015 \\
\cline { 2 - 4 } ISO 9001:2008 & \multicolumn{3}{l}{ ISO 9001:2015 } \\
\hline 0. & Pendahuluan & 0. & Pendahuluan \\
1. & Ruang Lingkup & 1. & Ruang Lingkup \\
2. & Acuan Normatif & 2. & Acuan Normatif \\
3. & Istilah Definisi & 3. & Istilah Definisi \\
4. & Sistem Manajemen Mutu & 4. & Konteks Organisasi \\
5. & Tanggungjawab Manajemen & 5. & Kepemimpinan \\
6. & Pengelolaan Sumber Daya & 6. & Perencanaan \\
7. & Realisasi Produk & 7. & Pendukung \\
8. & Pengukuran, Analisis, dan Peningkatan & 8. & Operasi \\
& & 9. & Evaluasi Kinerja \\
& & 10. & Peningkatan \\
\hline
\end{tabular}

Berdasarkan tabel 1 secara umum perubahan pendekatan manajemen dan struktur persyaratan dari ISO 9001:2008 ke ISO 9001:2015 adalah: 1) Lebih menekankan pada pendekatan pengembangan sistem manajemen mutu sesuai dengan kebutuhan spesifik pada setiap bagian di dalam suatu organisasi. 2)

\footnotetext{
${ }^{13}$ Tim Penyusun Kamus Besar Bahasa Indonesia, "Kamus Besar Bahasa Indonesia," Jakarta: Balai Pustaka, 2008. hlm. 132

${ }^{14}$ Adalia Martin and Fawaz Ali Thawabieh, "The Effect of ISO 9001 to Oman Higher Education Operational Performance: Buraimi University College as a Case Study," International Journal of Applied Engineering Research 13, no. 6 (2018): $3939-47$.

${ }^{15}$ Hasyim Asy' ari, Zahruddin Zahruddin, and Syipa Fauziah, "Implementasi Prinsip-Prinsip Sistem Manajemen Mutu ISO 9001: 2008 Di SMK Ekonomika Depok Jawa Barat," MANAGERIA: Jurnal Manajemen Pendidikan Islam 2, no. 2 (2017): $205-33$.

${ }^{16}$ Fitriana Fajrin Ramadhany, "Analisis Penerapan Sistem Manajemen Mutu Iso 9001: 2015 Dalam Menunjang Pemasaran (Studi Pada Pt Tritama Bina Karya Malang)" (Universitas Brawijaya, 2017). hlm. 33

${ }^{17}$ Manlian Ronald A Simanjuntak and Skarlet Sinta Suawa, "Analisis Sistem Manajemen Mutu Dan Pengaruhnya Dalam Meningkatkan Kinerja Operasional Bangunan Gedung Tinggi Perkantoran Di Jakarta Pusat," Jurnal IImiah Media Engineering 4, no. 2 (2014). hlm. 93 hlm. 4

${ }^{18}$ Muhammad Noor Efansyah dan agung Nugraha, Perkembangan Dan Penerapan Sistem Manajemen Mutu ISO 9001:2015.
} 
Mempersyaratkan kepada setiap personal di dalam organisasi harus terlibat dan bertanggungjawab untuk menyelaraskan faktor masalah mutu dengan strategi bisnis yang lebih luas. 3) Mempersyaratkan berpikir berbasis resiko sebagai perangkat pengendalian melalui identifikasi rencana pengelolaan resiko seluruh proses sistem manajemen untuk mendorong perbaikan berkelanjutan. 4) Mendorong upaya mengurangi aspek dokumentasi sebagai panduan dan bukti proses. Sehingga organisasi dapat memutuskan informasi dan format yang sesuai dan dibutuhkan untuk didokumentasikan. ${ }^{19}$

Jika dicermati standar Sistem Manajemen Mutu ISO 9001:2015 ini lebih memperhatikan pada kinerja sistem. Karena sejatinya upaya peningkatan kualitas suatu organisasi atau lembaga melalui penerapan SMM ISO 9001:2015 adalah dengan menggunakan pendekatan proses. Dalam pendeketan proses ini SMM ISO 9001:2015 menggabungkan antara siklus PDCA dengan pendekatan baru yaitu berpikir berbasis resiko. Siklus PDCA merupakan landasan yang digunakan dalam pelaksanaan sistem manajemen mutu sebagai upaya dalam melakukan perbaikan atau peningkatan berkelanjutan. Sebagai pencetus siklus PDCA, Deming mengatakan bahwa jika suatu organisasi ingin menghasilkan mutu dari produk/jasa maka roda PDCA harus berputar. ${ }^{20} \mathrm{Hal}$ ini berarti jika organisasi ingin menghasilkan mutu dari produk/jasanya maka organisasi tersebut harus menggunakan siklus PDCA.

Jika digambarkan siklus PDCA dalam pelaksanaan sistem manajemen mutu dalah sebagai berikut:

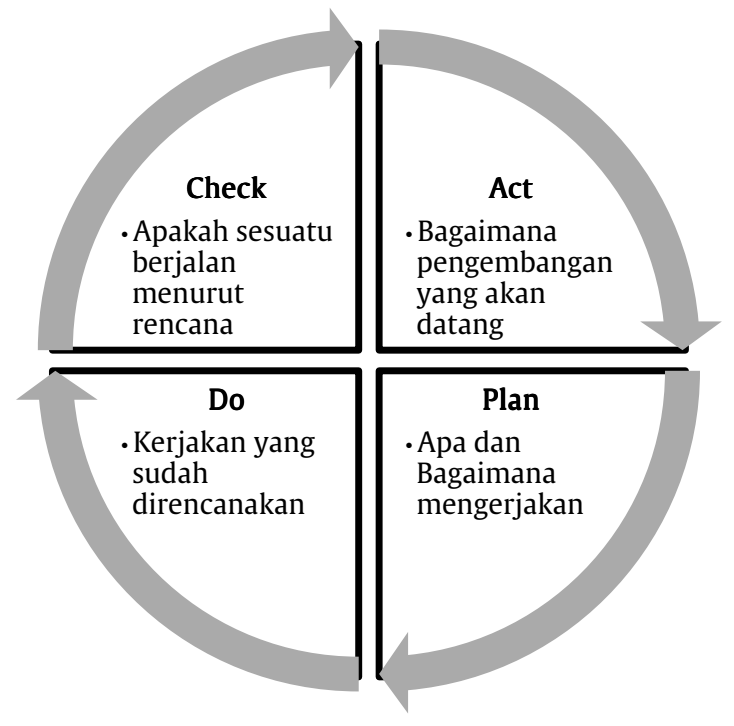

Gambar 1.

Landasan Proses Manajemen PDCA ${ }^{21}$

1. Plan (rencana), pada tahap ini organisasi menetapkan sasaran mutu dan bagaimana prosesnya serta sumber daya yang dibutuhkan untuk memenuhi persyaratan pelanggan. Selain itu organisasi harus menetapkan kebijakan-kebijakan yang akan ditempuh selanjutnya dengan mengidentifikasi dan menangani baik risiko maupun peluang. Kegiatan plan disini difokuskan pada pertanyaan "apa yang akan dikerjakan dan bagaimana mengerjakannya".

2. Do (lakukan), dalam kegiatan do ini berarti organisasi harus menerapkan apa yang sudah direncanakan pada plan. Di sinilah organisasi menjalankan suatu proses.

3. Check (monitoring), selama menjalankan prosesnya organisasi juga harus memantau jalannya proses kerja. Selain itu, organisasi juga diharap untuk mengukur proses-proses yang dikerjakan sesuai dengan apa yang sudah direncanakan atau tidak. Tidak terlupa organisasi juga harus melaporkan hasilnya.

4. Act (tindak lanjut), tahapan ini mengambil tindakan untuk meningkatkan kinerja proses serta pengembangan berkelanjutan. Kegiatan yang dilakukan pada tahhap ini adalah menjawab pertanyaan bagaimana pengembangan organisasi akan dilakukan? ${ }^{22}$

\footnotetext{
${ }^{19}$ Muhammad Noor Efansyah dan agung Nugraha. hlm. 46-47

${ }^{20}$ Prabowo, "Implementasi Sistem Manajemen Mutu ISO 9001: 2008 Di Perguruan Tinggi (Guidelines IWA-2)." hlm. 80

${ }^{21}$ Prabowo. hlm. 56

${ }^{22}$ Milena Alič, "Use of IT in ISO 9001 Systems for Better Process Management," Quality Management Systems, 2018, 83-
} 
Sedangkan pelaksanaan siklus PDCA pada SMM ISO 9001:2015 dapat diilustrasikan dengan gambar berikut ini:



Gambar 2.

Model Struktur Standar Sesuai Siklus PDCA ${ }^{23}$

Dari gambar di atas mengenai siklus PDCA (plan-do-check-act) dalam pelaksanaan sistem manajemen mutu ISO 9001:2015 dapat disimpulkan seperti berikut ini:

Tabel 2.

Siklus PDCA pada SMM ISO 9001:2015

\begin{tabular}{lll}
\hline Siklus & \multicolumn{2}{l}{ Klausul SMM ISO 9001:2015 } \\
\hline P (PLAN)Rencana & 4.0 & Konteks Organisasi \\
& 5.0 & Kepemimpinan \\
D (DO) Lakukan & 6.0 & Perencanaan \\
& 7.0 & Dukungan \\
C (CHECK) Monitoring & 8.0 & Operasi \\
A (ACT) Tindak Lanjut & 9.0 & Evaluasi Kinerja \\
\hline
\end{tabular}

\section{Implementasi Sistem Manajemn Mutu ISO 9001:2015 Berdasarkan Siklus PDCA (Plan-Do-Check-Act) di MA NU Banat Kudus}

Lembaga pendidikan atau madrasah yang telah menerapkan sistem manajemen mutu ISO 9001:2015 tentunya menuntut semua kegiatan atau program yang dilaksanakan selalu berorientasi pada mutu. Dengan demikian madrasah memerlukan dokumen panduan yang terstruktur secara baik. Dokumen panduan tersebut biasa disebut dengan dokumen mutu yang akan menuntun dan mengarahkan setiap orang dalam melaksanakan pekerjaannya dengan jelas. Dokumen mutu yang dimaksud terdiri dari manual mutu, POS (Prosedur Operasi Standar), dan IK (Instruksi Kerja).

MA NU Banat Kudus sebagai salah satu madrasah yang telah menerapkan SMM ISO 9001:2015 ini selalu berpegang pada prinsip utama mereka dalam melaksanakan SMM ISO 9001:2015, yaitu "Do What You Write, Write What You Do" (melaksanakan apa yang telah tertulis, dan menulis apa yang telah dikerjakan). Dengan menggunakan prinsip dasar tersebut, sistem manajemen mutu madrasah dapat berjalan dengan efekitif dan efisien. Hal ini karena keteraturan pekerjaan yang dikerjakan sesuai dengan rencana yang telah dirumuskan sebelumnya dan akan melaporkan/mendokumentasikan segala sesuatu yang telah dikerjakan. Dengan demikian apa yang dilakukan oleh MA NU Banat Kudus telah sesuai dengan

${ }^{23}$ Muhammad Noor Efansyah dan agung Nugraha, Perkembangan Dan Penerapan Sistem Manajemen Mutu ISO 9001:2015. 
pendapat Bunyamin Celik dan Omer Hakan Olcer yang mengatakan bahwa instansi yang telah memahami prinsip "Do What You Write, Write What You Do" pekerjaannya akan lebih jelas dan efektif. ${ }^{24}$

Proses pelaksanaan SMM ISO 9001:2015 di MA NU Banat Kudus adalah sebagai berikut:

\section{a. Plan(Perencanaan)}

Pada siklus PDCA, yang menempati tahapan plan sesuai teori ialah pada klausul 4.0. (Konteks Organisasi), 5.0. (Kepemimpinan), dan 6.0. (Perencanaan). Dalam praktiknya tahap perencanaan yang dilakukan MA NU Banat Kudus ialah: pertama, Merumuskan Sasaran Mutu; Jika dilihat dalam klausul persyaratan SMM ISO 9001:2015 sasaran mutu terdapat pada klausul 6.2. Langkah awal yang dilakukan MA NU Banat Kudus dalam tahap perencanaan ini ialah merumuskan sasaran mutu masing-masing unit kerja. Sasaran mutu dirumuskan dengan tetap memerhatikan kebijakan mutu madrasah. Adanya kebijakan mutu ini sebagai wujud dari komitmen kepala madrasah sebagai top management dalam menjalankan kepemimpinannya (klausul 5.0). Dalam merumuskan sasaran mutu MA NU Banat Kudus selalu memperhatikan: 1) sasaran mutu harus dimutakhirkan. Dalam prakteknya MA NU Banat Kudus selalu memutakhirkan sasaran mutu, baik sasaran mutu madrasah ataupun sasaran mutu masing-masing unit kerja. Perumusan sasaran mutu biasanya dilakukan pada awal tahun pelajaran. Pemutakhiran sasaran mutu didasarkan pada kebutuhan dan target madrasah yang hendak dicapai pada tahun itu. Pada sasaran mutu madrasah tahun pelajaran yang lalu berbunyi " 3 . Tercapainya nilai UN tingkat Jateng peringkat 4 program IPA, peringkat 7 program IPS, peringkat 1 program bahasa, dan peringkat 7 program PK. 4. Tercapainya nilai UAMBN tingkat kabupaten peringkat 1 dan tingkat provinsi peringkat 6." Untuk tahun pelajaran tahun ini sasaran mutu tersebut dihapuskan. Hal ini dilatarbelakangi oleh dikeluarkannya permendikbud tentang penghapusan ujian nasional. Ini sesuai dengan klausul persyaratan SMM ISO 9001:2015, yaitu klausul 6.2.1 sasaran mutu harus: (g) dimutakhirkan seperlunya. ${ }^{25}$ 2) Kedua, sasaran mutu harus terukur. Perumusan sasaran mutu selalu mengandung informasi nilai atau ukuran sesuai dengan subjek yang akan ditingkatkan. Pada prakteknya setiap masing-masing unit kerja dalam merumuskan sasaran mutu juga disertai dengan menetapkan grade yang hendak dicapai. Misalnya pada sasaran mutu MA NU Banat Kudus "Tercapainya peringkat 1 tingkat kabupaten untuk 2 mata pelajaran dalam KSM dan mewakili kabupaten dalam KSN". Dengan demikian target atau sasaran mutu lebih jelas dan terukur. Ini sesuai dengan klausul persyaratan SMM ISO 9001:2015, yaitu klausul 6.2.1 sasaran mutu harus: (b) terukur. ${ }^{26}$ 3) sasaran mutu selalu konsisten pada kebijakan mutu. Dalam merumuskan dan menetapkan sasaran mutu pada seluruh unit kerja mengacu pada pernyataan dalam kebijakan mutu madrasah yang telah ditetapkan sebelumnya. Sebagai contoh dapat dilihat pada sasaran mutu unit kerja kepala tata usaha MA NU Banat Kudus, salah satunya adalah "tercapainya layanan surat-menyurat keterangan maksimal 1 hari pada hari efektif". Sasaran mutu tersebut jelas terlihat nyata berpedoman dan mengacu pada salah satu kebijakan mutu madrasah yang berbunyi "memberikan pelayanan prima pada semua kegiatan dalam rangka mewujudkan kepuasan pelanggan". Ini sesuai dengan klausul persyaratan SMM ISO 9001:2015, yaitu klausul 6.2.1 sasaran mutu harus: (a) konsisten dengan kebijakan mutu. ${ }^{27}$ 4) sasaran mutu harus dikomunikasikan. Dalam pelaksanaan upaya pencapaian sasaran mutu, tim manajemen mutu MA NU Banat Kudus selalu mengkomunikasikannya. Mengkomunikasikan di sini berarti pihak tim manajemen mutu madrasah menyampaikan progres pencapaian sasaran mutu masing-masing unit kerja secara berkala. Ini sesuai dengan klausul persyaratan SMM ISO 9001:2015, yaitu klausul 6.2.1 sasaran mutu harus: (f) dikomunikasikan. Organisasi harus memiliki mekanisme untuk mengkomunikasikan status pencapaian sasaran mutu. ${ }^{28}$

Kedua, merumuskan Isu-isu internal dan eksternal; setelah merumuskan sasaran mutu, langkah yang diambil oleh tim manajemen mutu MA NU Banat Kudus adalah merumuskan isu-isu internal dan eksternal. Dalam klausul persyaratan SMM ISO 9001:2015 isu-isu internal dan eksternal masuk pada klausul 4.1 yaitu memahami organisasi dan konteksnya. Dimana klausul 4 pada siklus PDCA termasuk dalam tahap plan. Isu internal ialah masalah-masalah yang mungkin muncul dari dalam organisasi atau madrasah itu sendiri

${ }^{24}$ Celik and Ölçer, "What Is the Contribution of ISO 9001 Quality Management System to Educational Institutions?" hlm.

451

${ }^{25}$ Muhammad Noor Efansyah dan agung Nugraha, Perkembangan Dan Penerapan Sistem Manajemen Mutu ISO 9001:2015. hlm. 157

${ }^{26}$ Muhammad Noor Efansyah dan agung Nugraha. hlm. 187

${ }^{27}$ Muhammad Noor Efansyah dan agung Nugraha.

${ }^{28}$ Muhammad Noor Efansyah dan agung Nugraha. 
untuk seluruh unit kerja. Sedangkan isu eksternal adalah masalah yang mungkin muncul dari pihak eksternal (luar) madrasah dan berpotensi resiko kepada madrasah. Dalam merumuskan isu-isu internal dan eksternal ini disertai dengan tindak lanjut, penanggungjawab, dan tanggal penyelesaian untuk melaksanakan tindak lanjut tersebut.

Ketiga, Merumuskan Peluang dan Resiko; perumusan peluang dan resiko merupakan tahap lanjutan dari kegiatan identifikasi isu-isu internal dan eksternal sebagai bagian konteks dari organisasi. Merumuskan peluang dan resiko ini terdapat pada klausul 6.1 pada klausul persyaratan SMM ISO 9001:2015. Poin-poin yang dirumuskan oleh tim manajemen mutu MA NU Banat Kudus dalam tabel peluang dan resiko adalah identifikasi resiko/peluang, konsekuensinya apa, menentukan analisa bobot resiko, tindakan antisipasi, penanggungjawab, waktu pelaksanaan, target pencapaian, dan periode monitoring.Dengan adanya tabel resiko dan peluang ini memberikan manfaat kepada madrasah diantaranya adalah mencegah pengaruh yang tidak diinginkan atau kendala pencapaian sistem manajemen mutu madrasah. Dengan demikian dengan adanya tabel resiko dan peluan ini dapat memastikan bahwa sistem manajemen mutu madrasah akan tercapai dan selalu terjadi peningkatan mutu madrasah.

Keempat, merumuskan Kebutuhan dan Harapan Pihak Berkepentingan, tim manajemen mutu hendaknya memahami siapa saja pihak berkepentingan yang dimaksud. Dengan mengetahui siapa saja pihak berkepentingan tersebut, maka masing-masing unit kerja akan memahami kebutuhan dan harapan untuk mencapai sasaran mutu yang telah dirumuskan sebelumnya. Karena SMM ISO 9001:2015 ini diterapkan di lembaga pendidikan, maka pihak berkepentingan di sini salah satunya adalah peserta didik. Dalam tabel klausul persyaratan SMM ISO 9001:2015 kebutuhan dan harapan pihak berkepentingan ini merupakan klausul 4.2.

\section{b. Do (Laksanakan)}

Tahap pelaksanaan SMM ISO 9001:2015 jika dilihat pada siklus PDCA mencakup dukungan pada klausul 7.0 dan operasi pada klausul 8.0 dalam klausul persyaratan SMM ISO 9001:2015.29

\section{Dukungan-dukungan}

Pelaksanaan ISO 9001:2015 dapat sukses tidak terlepas dari dukungan-dukungan yang ada dalam lingkungan organisasi atau madrasah. Komponen dukungan yang menjadikan MA NU Banat Kudus berhasil melaksanakan penerapan SMM ISO 9001:2015 adalah:

Pertama, adalah sumber daya. Sumber daya pertama yang berpengaruh dan menjadi pendukung untuk tercapainya pelaksanaan SMM ISO 9001:2015 adalah adanya sumber daya manusia. Di MA NU Banat Kudus penanggungjawab mutu madrasah tergabung dalam tim manajemen mutu. Tim manajemen mutu MA NU Banat Kudus terdiri dari unit kerja kepala madrasah selaku top magement, staf manajemen mutu, unit kerja waka kurikulum, unit kerja waka kesiswaan, unit kerja waka humas dan agama, unit kerja waka sarana dan prasarana, unit kerja kepala tata usaha, unit kerja koordinator bimbingan dan konseling, dan unit kerja kepala perpustakaan. Namun untuk tercapainya keberhasilan yang maksimal seluruh warga MA NU Banat Kudus juga ikut terlibat di dalamnya, mulai dari yayasan (BPPPM NU Banat Kudus), pendidik, tenaga kependidikan, staf karyawan madrasah, dan peserta didik.

Sumber daya yang kedua ialah tersedianya sarana dan prasarana. Sarana dan prasarana dirasa sangat dibutuhkan dalam mensukseskan ISO 9001:2015 di MA NU Banat Kudus. Pihak madrasah selalu berupaya untuk memenuhi sarana dan prasarana yang dibutuhkan guna menunjang tercapainya sasaran atau target yang sudah direncanakan.

Kedua, ialah komitmen kerjasama tim. Komitmen kerjasama tim manajemen mutu terlihat dari konsistensi dan komitmen tim manajemen mutu madrasah dalam melaksanakan apa yang sudah direncanakan sebelumnya, yaitu kebijakan mutu madrasah dan tercapainya sasaran mutu semua unit kerja. Maka dari itu tim manajemen mutu akan membentuk suasana lingkungan kerja yang efektif seingga dapat saling membantu.

Ketiga, kompetensi sumber daya manusia. Komitmen tinggi dalam mlaksanaan penerapan SMM ISO 9001:2015 tanpa didasari dengan pengetahuan yang mendalam mengenai apa dan bagaimana ISO 9001:2015, keberhasilan itu akan sirna. Upaya yang dilakukan oleh MA NU Banat Kudus dalam membekali tim manajemen mutu untuk meningkatkan kompetensi tim manajemen mutu ialah dengan mengadakan workshop pelatihan ISO. Workshop ini diselenggarakan dengan mendatangkan narasumber dari pihak

\footnotetext{
${ }^{29}$ Muhammad Noor Efansyah dan Agung Nugraha, Perkembangan dan Penerapan..., hlm. 57.
} 
sertifikasi terkait. Selain itu, untuk menunjang keberhasilan apa yang sudah diprogramkan sebelumnya, maka dalam POS (Prosedur Operasi Standar) MA NU Banat Kudus selalu melakukan upaya pengembangan kompetensi guru (7.1.2.a) dan pengembangan kompetensi tenaga Tata Usaha (7.1.2.b).

Keempat, ialah komunikasi. Komunikasi antar sesama tim manajemen mutu ternyata merupakan salah satu pendukung untuk suksesnya penerapan SMM ISO 9001:2015. Komunikasi terjalin dengan baik di MA NU Banat Kudus, baik yang terencana maupun tidak terencana. Komunikasi yang terencana dapat dilihat dari pertemuan-pertemuan antar tim manajemen mutu yang telah diagendakan, seperti rapat mingguan (Senin-an), forum koordinasi koordinasi 27-an, dan rapat-rapat insidental. Sedangkan komunikasi yang tidak terencana terjadi ketika masing-masing unit kerja berkomunikasi baik secara langsung maupun tidak langsung diluar dari rapat yang telah diagendakan. Komunikasi tersebut tentu untuk membahas berbagai hal mengenai ISO 9001:2015 yang telah dilaksanakan namun tidak formal.

Kelima, ialah adanya dokumen mutu. Dokumen mutu juga termasuk pendukung yang sangat diperlukan dalam pelaksanaan penerapan ISO 9001:2015. Dokumen mutu yang dimaksud adalah manual mutu, POS (Prosedur Operasi Standar), dan IK (Instruksi Kerja). Selain ketiga dokumen tersebut form rekaman dari setiap prosees juga sangat dibutuhkan untuk dijadikan sebagai bukti dari terselenggaranya proses.

\section{Pengendalian Operasional}

Pelaksanaan penerapan SMM ISO 9001:2015 di MA NU Banat Kudus tentunya tidak luput dari pengendalian operasional dari para unit kerja utamanya top management. Operasional madrasah yang tertera pada POS (Prosedur Operasi Standar) berada pada tanggungjawab unit kerja waka kurikulum, unit kerja waka kesiswaan, unit kerja koordinator BK, unit kerja waka sarpras, dan unit kerja kepala perpustakaan.

Unit kerja waka kurikulum bertanggungjawab dalam merumuskan penyusunan kalender pendidikan, proses kegiatan pembelajaran, penyusunan kurikulum, penyusunan perangkat pembelajaran, dan penilaian. Unit kerja waka kesiswaan terdiri dari penerimaan peserta didik, Masa Pengenalan Lingkungan Madrasah (MPLM), dan kegiatan ekstrakurikuler. Pada unit kerja waka sarpras bertanggungjawab dalam pembelian sarana prasarana pembelajaran. Unit koordinator BK bertanggungjawab untuk memberikan bimbingan konseling dan melakukan penyusunan prosedur penelusuran tamatan. Sedangkan pada unit kepala perpustakaan bertanggungjawab dalam pengadaan buku perpustakaan, pengolahan buku perpustakaan, dan pelayanan perpustakaan.

Dalam mengendalikan segala operasional yang telah tertulis dalam dokumen SMM ISO 9001:2015 tersebut upaya yang dilakukan oleh tim manajemen mutu MA NU Banat Kudus adalah melalui rapat mingguan (Senin-an). Pada rapat ini maisng-masing unit kerja melaporkan kegiatan atau program yang telah dilaksanakan satu minggu yang lalu, dan rencana untuk satu minggu yang akan datang. Sedaangkan untuk pengendali rekaman ISO 9001:2015 diadakan forum koordinasi rapat bulanan setiap tanggal 27.

\section{c. Check(Pemeriksaan)}

Tahap pemeriksaan (check) pada siklus PDCA dalam klausul persyaratan SMM ISO 9001:2015 terdapat pada klausul 9.0 (evaluasi kinerja). ${ }^{30}$ MA NU Banat Kudus dalam melaksanakan evaluasi kinerja melakukan beberapa hal berikut ini:

Pertama, menyebarkan angket kepuasan peserta didik terhadap layanan. Penyebaran angket ini bertuuan untuk mengetahui sejauh mana keberhasilan kinerja madrasah dalam memenuhi kepuasan peserta didik MA NU Banat Kudus. Jenis pelayanan yang akan dinilai dalam angket tersebut meliputi pibadi, administrasi peserta didik, kegiatan pembelajaran, pelayanan program jurusan, bidang pelayanan BK, fasilitas madrasah, fasilitas kelas, dan fasilitas penunjang. Hasil dari penilaian angket ini dapat diketahui apakah peserta didik puas dengan layanan yang telah diberikan oleh madrasah. Hal ini sebagai wujud penyesuaian dengan persyaratan klausul SMM ISO 9001:2015, yaitu pada klausul 9.1.2 kepuasan pelanggan. ${ }^{31}$

Kedua, melaksanakan audit internal. Pada persyaratan klausul SMM ISO 9001:2015 audit internal terdapat pada klausul 9.2.32 Audit internal dilaksanakan dua kali dalam satu tahun dan biasanya

\footnotetext{
${ }^{30}$ Muhammad Noor Efansyah dan agung Nugraha, Perkembangan Dan Penerapan Sistem Manajemen Mutu ISO 9001:2015. hlm. 50

${ }^{31}$ Muhammad Noor Efansyah dan agung Nugraha. hlm. 371

${ }^{32}$ Muhammad Noor Efansyah dan agung Nugraha. hlm. 381
} 
dilaksanakan pada akhir semesester. Pelaksanaan audit internal diatur sedemikian rupa oleh staf manajemen mutu madrasah beserta top management termasuk penentuan siapa yang menjadi auditor. Audit internal dilaksanakan secara silang, sehingga satu unit kerja dapat mengaudit unit kerja yang lain. Auditor pada audit internal ini dipilih berdasarkan kriteria telah memiliki pengetahuan mengenai ISO yang mendalam dibuktikan dengan telah lolos mengikuti pelatihan.

Ketiga, melaksanakan audit eksternal. Setelah dilakukan audit internal maka selanjutnya akan dilaksanakan audit eksternal. Audit eksternal dilaksanakan satu tahun sekali oleh lembaga sertifikasi ISO. Audit eksternal di MA NU Banat Kudus biasanya dilaksanakan pada bulan November setiap tahunnya. Dalam pelaksanaan audit eksternal MA NU Banat Kudus bekerjasama dengan PT. MSA Certification, Jakarta.

Keempat, Rapat Tinjauan Manajemen. Hal ini sesuai dengan persyaratan klausul SMM ISO 9001:2015 pada klausul 9.3 tinjauan manajemen. ${ }^{33}$ Rapat Tinjauan Manajemen pada dasarnya dilaksanakan untuk melakukan tindakan yang harus diambil jika ada penyimpangan-penyimpangan dalam pelaksanaan penerapan sistem manajemen mutu ISO 9001:2015. Jika memang hal tersebut terjadi pada salah satu unit kerja, maka unit kerja yang bersangkutan tersebut mengajukan kepada staf manajemen mutu madrasah untuk diadakan Rapat Tinjauan Manajemen bersama top management beserta tim manajemen mutu yang lain.

\section{d. $\quad$ Act (Tindakan)}

Tindakan (act) pada siklus PDCA menempati tahapan paling akhir namun bukan berarti berhenti disitu. Karena pada tahap ini merupakan upaya madrasah untuk melakukan peningkatan berkelanjutan. Peningkatan berkelanjutan terdapat pada klausul 10.0 dalam klausul persyaratan SMM ISO 9001:2015. Peningkatan ini merupakan tindakan yang ditetapkan oleh madrasah untuk memperbaiki penerapan sistem manajemen mutu. Pada tahap ini upaya yang dilakukan oleh MA NU Banat Kudus adalah dengan menggunakan hasil analisis penilaian angket kepuasan peserta didik. Dari hasil angket tersebut akan diketahui bagian mana yang harus diperbaiki agar kinerja madrasah dalam melaksanakan SMM ISO 9001:2015 semakin meningkat dan kepuasan peserta didik tercapai.

Tindakan perbaikan sebagai bentuk peningkatan berkelanjutan yang juga dilakukan oleh MA NU Banat Kudus adalah dengan meningkatkan grade pada sasaran mutu yang telah dicapai pada tahun sebelumnya. Namun tentunya hal itu dilakukan dengan melihat resiko dan peluang yang dimiliki madrasah. Salah satu contoh tindakan perbaikan sebagai wujud peningkatan mutu MA NU Banat Kudus dapat dilihat dari adanya masalah yang dialami madrasah yaitu "peserta didik yang berasal dari SMP kurang memahami mapel takhassus (bahasa arab/kitab kuning). Dengan adanya masalah tersebut tindakan yang diambil oleh madrasah adalah dengan melaksanakan kegiatan matrikulasi untuk peserta didik yang membutuhkan.

\section{Implikasi Implementasi Sistem Manajemen Mutu ISO 9001:2015 di MA NU Banat Kudus}

Setelah SMM ISO 9001:2015 berhasil diterapkan dalam dunia pendidikan, maka akan muncul implikasi dari penerapan SMM ISO 9001:2015 tersebut. Bagi MA NU Banat Kudus sebagai madrasah yang telah menerapkan ISO sejak dulu, khususnya pada saat ini menerapkan SMM ISO 9001:2015, implikasi yang terlihat ialah sangat membantu persiapan akreditasi madrasah. Dengan diterapkannya SMM ISO 9001:2015 di MA NU Banat Kudus ini sangat membantu madrasah dalam hal kaitannya dengan administrasi persiapan akreditasi. Karena dapat diketahui bahwa unit kerja yang ada dalam ISO 9001:2015 ini sebagian besar juga termasuk standar yang dinilai saat akreditasi. Hal ini terbukti bahwa akreditasi MA NU Banat Kudus dengan konsisten selalu mendapatkan predikat A.

Citra madrasah juga meningkat setelah diterapkannya SMM ISO 9001:2015. Berhasilnya madrasah dalam menerapkan SMM ISO 9001:2015 dibuktikan dengan diterimanya sertifikat ISO 9001:2015 berskala internasional dari lembaga sertifikasi terkait. Bagi madrasah yang telah mendapatkan sertifikat tersebut ia akan lebih diyakini oleh pelanggan dan kepercayaan pelanggan terhadap madrasah semakin meningkat. Ini menunjukkan madrasah berhasil memberikan citra yang baik bagi pelanggannya, baik pelanggan internal maupun pelanggan eksternal.

Dokumen-dokumen mutu yang di dalamnya menjelaskan tentang gambaran kerja masing-masing tim manajemen mutu sangat berpengaruh bagi kinerja pegawai (tim manajemen mutu beserta warga madrasah yang lain). Dengan adanya dokumen tersebut kegiatan atau segala proses pelaksanaan program

\footnotetext{
${ }^{33}$ Muhammad Noor Efansyah dan agung Nugraha. hlm. 391
} 
di madrasah dapat terkendali karena tugas yang dijabarkan sudah jelas. Dengan berprinsip "Do What You Write, Write What You Do", maka perlu adanya komitmen warga madrasah dengan kesadaran penuh untuk sama-sama melaksanakan segala sesuatu yang sudah direncanakan dengan baik. Karena semua yang telah dilaksanakan akan dilaporkan. Untuk itu kedisiplinan warga madrasah baik pendidik, tenaga kependidikan, staf/karyawan, dan peserta didik otomatis akan meningkat.

\section{SIMPULAN}

Penelitian mengenai implementasi sistem manajemen mutu ISO 9001:2015 di MA NU Banat Kudus yang telah dilakukan oleh penulis, dapat diketahui bahwa dalam melaksanakan SMM ISO 9001:2015 MA NU Banat Kudus menggunakan siklus PDCA. Tahap perencanaan (plan) terdiri dari merumuskan sasaran mutu, merumuskan isu-isu internal dan eksternal, merumuskan resiko peluang, serta merumuskan kebutuhan dan harapan pihak berkepentingan. Tahap pelaksanaan (do) yang perlu diperhatikan adalah dukungan-dukungan dan pengendalian operasional. Tahap selanjutnya ialah pemeriksaan (check), pada tahap ini yang dilakukan oleh MA NU Banat Kudus ialah menyebarkan angket kepuasan peserta didik terhadap layanan, audit internal, audit eksternal, serta dilaksanakannya Rapat Tinjauan Manajemen. Tahap terakhir pada siklus PDCA ialah tindakan (act). MA NU Banat Kudus menggunakan hasil angket layanan tersebut untuk dijadikan pijakan perbaikan pada tahun selanjutnya. Selain itu, untuk melakukan peningkatan/perbaikan berkelanjutan MA NU Banat Kudus meningkatkan/menaikkan grade pada sasaran mutu yang dirasa memang perlu. dengan adanya SMM ISO 9001:2015 di MA NU Banat Kudus ini sangat memabantu adminitrasi untuk persiapan akreditasi madrasah. Dengan didapatkannya sertifikat berskala internasional, tentu dapat meningkatkan citra madrasah. Selain itu dengan adanya SMM ISO 9001:2015 kegiatan/program madrasah terkendali dan kedisiplinan warga madrasah meningkat.

\section{DAFTAR PUSTAKA}

20, Undang-undang No. Sistem Pendidikan Nsional Pasal 3, issued 2003.

Alič, Milena. "Use of IT in ISO 9001 Systems for Better Process Management." Quality Management Systems, 2018, 83-114.

Asmara, Rini, S Kom, and M Kom. "Sistem Informasi Pengolahan Data Penanggulangan Bencana Pada Kantor Badan Penanggulangan Bencana Daerah (BPBD) Kabupaten Padang Pariaman." Jurnal J-Click 3, no. 2 (2017).

Asy' ari, Hasyim, Zahruddin Zahruddin, and Syipa Fauziah. "Implementasi Prinsip-Prinsip Sistem Manajemen Mutu ISO 9001: 2008 Di SMK Ekonomika Depok Jawa Barat." MANAGERIA: Jurnal Manajemen Pendidikan Islam 2, no. 2 (2017): 205-33.

Celik, Bünyamin, and Ömer Hakan Ölçer. "What Is the Contribution of ISO 9001 Quality Management System to Educational Institutions?" International Journal of Academic Research in Business and Social Sciences 8, no. 6 (2018).

Fadhli, Muhammad. "Manajemen Peningkatan Mutu Pendidikan." Tadbir: Jurnal Studi Manajemen Pendidikan 1, no. 2 (2017): 215-40.

Imam, Gunawan. "Metode Penelitian Kualitatif Teori Dan Praktik." Jakarta: Bumi Aksara, 2013.

Indonesia, Tim Penyusun Kamus Besar Bahasa. "Kamus Besar Bahasa Indonesia." Jakarta: Balai Pustaka, 2008.

Iskarim, Mochamad. "The Quality Management of Arabic Language Education Based on The Quality Management System (SMM) ISO 9001: 2015." ALSINATUNA3, no. 2 (2018): 225-43.

Martin, Adalia, and Fawaz Ali Thawabieh. "The Effect of ISO 9001 to Oman Higher Education Operational Performance: Buraimi University College as a Case Study." International Journal of Applied Engineering Research 13, no. 6 (2018): 3939-47.

Muhammad Noor Efansyah dan agung Nugraha. Perkembangan Dan Penerapan Sistem Manajemen Mutu ISO 9001:2015. Banten: Wana Aksara, 2019.

Prabowo, Sugeng Listyo. "Implementasi Sistem Manajemen Mutu ISO 9001: 2008 Di Perguruan Tinggi (Guidelines IWA-2)." UIN-Maliki Press, 2009.

Ramadhany, Fitriana Fajrin. "Analisis Penerapan Sistem Manajemen Mutu ISO 9001: 2015 dalam 
Menunjang Pemasaran (Studi pada PT Tritama Bina Karya Malang)." Universitas Brawijaya, 2017. Saleh, Abdul Rahman, Erni Sumarni, and Sri Rahayu Safitri. "Kajian Analisis Kepuasan Pelanggan Pada Layanan Perpustakaan Badan Standardisasi Nasional." Jurnal Pustakawan Indonesia 13, no. 2 (2014).

Simanjuntak, Manlian Ronald A, and Skarlet Sinta Suawa. "Analisis Sistem Manajemen Mutu Dan Pengaruhnya Dalam Meningkatkan Kinerja Operasional Bangunan Gedung Tinggi Perkantoran Di Jakarta Pusat." Jurnal Ilmiah Media Engineering 4, no. 2 (2014). 